Vol 2 No 1 Juli 2021

Jurnal AlphaEuclidEdu

Received:04/05/2021; Resived:04/06/2021; Accepted:04/07/2021

\title{
PENGARUH PENGGUNAAN MODEL PEMBELAJARAN KOOPERATIF TIPE INSIDE OUTSIDE CIRCLE (IOC) TERHADAP HASIL BELAJAR
}

\author{
${ }^{1}$ Endar Sulistyowati \\ ${ }^{\text {IDosen }}$ di STKIP Kumala Metro Lampung \\ email:endar.sulistyowati@kumala.ac.id
}

\begin{abstract}
The purpose of this study was to determine the effect of the Inside Outside Circle (IOC) cooperative learning model on the learning outcomes of eighth grade students of SMP Negeri 4 Metro. The method that will be used in this study is a true experimental design using a pretestposttest control group design. This research was conducted by 22 students of class VIII B SMP Negeri 4 Metro even semester as samples. After receiving treatment using the Inside Outside Circle (IOC) type of cooperative learning model, student learning outcomes have increased seen from the comparison in the pretest and posttest evaluations, namely students who achieve KKM in the pretest evaluation are $27.27 \%$ or 6 students from a total of 22 students. While the students who achieved the KKM in the posttest evaluation were $68.18 \%$, namely 15 students from a total of 22 students. This is evidenced again by the calculation of data analysis using the Simple Linear Regression formula obtained $=55.5505+b=0.3183$ so that $Y=+b x$ is $(Y)$ $=55.5505+0.3183 x$ and the analysis calculation that t_hitung $>$ t_tab which is seen at a significant level of 5\%, namely $2.90>1.72$. And at a significant level of $1 \%$, namely 2.90> 2.53. Which can be seen in the table G statistics. Thus, the hypothesis is accepted. So it can be concluded that "there is a positive influence of the Inside Outside Circle (IOC) type of cooperative learning model on the learning outcomes of class VIII students of SMP Negeri 4 Metro in even semesters"
\end{abstract}

Keyword : Inside Outside Circle (IOC) type cooperative learning model, Results Study

\section{PENDAHULUAN}

Pendidikan merupakan salah satu faktor penting dalam perkembangan suatu negara. Kemajuan suatu negara dalam segala bidang baik ekonomi, bidang teknologi, bidang pertanian, maupun bidang-bidang yang lainya tidak terlepas dari pendidikan. Hal ini dikarenakan orang cerdas atau berpendidikan akan mampu memberikan kontribusi yang positif bagi peradaban suatu negara.

Perkembangan pendidikan di Indonesia yang perlu diperhatikan bahwa pendidikan akan berhasil dengan maksimal manakala setiap elemen dari pendidikan senantiasa memegang teguh tujuan pendidikan nasional. Adapun tujuan pendidikan nasional menurut UU No. 20 tahun 2003 disebutkan bahwa "tujuan pendidikan nasional berfungsi mengembangkan kemampuan dan membentuk watak serta peradaban bangsa yang bermartabat dalam rangka mencerdaskan kehidupan bangsa, bertujuan untuk berkembangnya potensi peserta didik agar menjadi manusia yang beriman dan bertakwa kepada Tuhan Yang Maha Esa, berahlak mulia, sehat, berilmu, cakap, kreatif, mandiri dan menjadi warga negara yang demokratis serta bertanggung jawab (Depdiknas,2003)". 
Vol 2 No 1 Juli 2021

Jurnal AlphaEuclidEdu

Received:04/05/2021; Resived:04/06/2021; Accepted:04/07/2021

Meningkatnya mutu pendidikan dapat terwujud dalam proses pembelajaran yang tidak hanya ditentukan oleh faktor-faktor kurikulum dan kemampuan guru dalam proses pembelajaran saja, melainkan dengan menggunakan metode-metode pembelajaran peserta didik sangat berpengaruh dalam menentukan keberhasilan dalam proses pembelajaran. Kesempurnaan kurikulum yang mendasari ilmu dan teknologi telah telah diterapkan dalam lembaga pendidikan guna membentuk kader-kader pembangunan yang nantinya akan menentukan keberhasilan pada pendidikan berikutnya. Dalam penggunaan dan pemilihan metode pembelajaran yang tepat akan membantu berhasilnya tujuan pembelajaran. Kesemuanya ini mempunyai maksud dan tujuan untuk meningkatkan mutu pendidikan. Mutu pendidikan peserta didik dapat dilihat dari hasil belajar peserta didik.

Proses pembelajaran merupakan bagian terpenting dalam proses pendidikan yang didalamnya terdapat guru sebagai pengajar dan peserta didik yang sedang belajar. Keberhasilan suatu pendidikan salah satunya ditentukan oleh bagaimana proses pembelajaran itu berlangsung. Selain itu proses interaksi belajar pada prinsipnya tergantung pada guru dan peserta didik. Guru dituntut untuk menciptakan suasana belajar yang efektif. Sedangkan peserta didik dituntut adanya motivasi dan dorongan untuk aktif dalam proses pembelajaran. Sehingga keberhasilan belajar dalam bidang kognitif, efektif dan psikomotorik dapat tercapai.

Berbagai upaya telah dilakukan dalam rangka meningkatkan mutu pendidikan di SMP Negeri 4 Metro, antara lain melengkapi buku-buku perpustakaan, mendisplinkan dalam proses pembelajaran baik peserta didik maupun guru. Setiap guru mata pelajaran wajib membuat perangkat-perangkat pembelajaran seperti program tahunan, program semester, silabus, rencana pelaksanaan pembelajaran. Juga ditambah adanya kegiatan belajar di luar jam sekolah yang sudah terjadwal dengan baik. Para guru juga sudah berusaha melaksanakan pembelajaran dengan baik dan juga sudah menggunakan metode pembelajaran seperti tanya jawab dan diskusi. Namun, masih terlihat bahwa hasil dari pengembangan proses pembelajaran yang diterapkan oleh guru belum memuaskan dan metode diskusi tersebut kurang memperhatikan kerjasama kelompok antar peserta didik. Permasalahannya pembelajaran yang dihadapi oleh peserta didik saat ini adalah peserta didik kesulitan mengkontruksikan ide-idenya sendiri dalam mengingat materi yang diberikan oleh guru dan juga hubungan antara peserta didik yang kurang dapat bekerjasama. Oleh karena itu, usaha yang dilakukan guru saat ini belum dapat meningkatkan Hasil belajar peserta didik secara maksimal.

Hal ini terlihat dari hasil pra survei ulangan harian peserta didik kelas VIII semester ganjil SMP Negeri 4 Metro, peneliti memperoleh data bahwa masih banyak peserta didik yang memperoleh nilai Hasil belajar peserta didikdi bawah kriteria ketuntasan minimal (KKM). Dimana jumlah peserta didik yang memperoleh nilai kategori tuntas sebanyak 8 peserta didik dengan presentase $36,36 \%$ dan kategori yang tidak tuntas sebanyak 14 peserta didik dengan preentase 63,64\% dari 22 peserta didik. Dengan kriteria ketuntasan minimal (KKM) senilai 75. Jadi, banyak peserta didik yang dinyatakan belum mencapai kelulusan dalam belajar. 
Vol 2 No 1 Juli 2021

Jurnal AlphaEuclidEdu

Received:04/05/2021; Resived:04/06/2021; Accepted:04/07/2021

Rendahnya Hasil belajar peserta didik tersebut tentu saja dipengaruhi beberapa faktor. Secara garis besar, faktor-faktor tersebut terdiri dari faktor internal dan eksternal. Adapun faktor internal ini berkaitan dengan segala sesuatu yang berkaitan dengan diri peserta didik itu sendiri yaitu berupa kondisi fisik yang normal, kondisi kesehatan fisik, intelegensi, kemauan serta bakat. Sedangkan, faktor eksternal berhubungan dengan pengaruh yang datang dari luar diri peserta didik yaitu berupa lingkungan keluarga yang nyaman, metode pembelajaran, kurikulum, interaksi guru dengan peserta didik, interaksi peserta didik dengan peserta didik, pelajaran, waktu sekolah dan juga lingkungan masyarakat berupa lembaga-lembaga pendidikan non formal.

Peneliti membatasi penelitian ini dengan mengambil salah satu faktor eksternal yang mempengaruhi hasil belajar peserta didik yaitu model pembelajaran, adapun model pembelajaran yang dimaksud adalah model pembelajaran kooperatif tipe Inside Outside Circle (IOC) .Dimana model pembelajaran kooperatif tipe Inside Outside Circle (IOC) adalah salah satu model pembelajaran dengan sintaks: pengarahan, buat kelompok heterogen, dengan membentuk lingkaran kecil dan lingkaran besar di mana peserta didik saling membagi informasi pada saat yang bersamaan dengan pasangan yang berbeda dengan singkat dan teratur. Pembelajaran ini juga melibatkan lebih banyak peserta didik yang menelaah materi yang tercakup dalam suatu pembelajaran dan mengecek pemahaman mereka terhadap isi pelajaran tersebut.

Berdasarkan uraian di atas, artikel ini ditulis dengan tujuan untuk mengetahui pengaruh model pembelajaran kooperatif tipe Inside Outside Circle (IOC) terhadap Hasil belajar peserta didik kelas VIII SMP Negeri 4 Metro.

\section{METODE PENELITIAN}

Penelitian ini merupakan penelitian yang bersifat pengaruh, yang mengkaji pengaruh antara variabel bebas dan variabel terikat. Penelitian ini mencari bagaimana pengaruh penggunaan model pembelajaran kooperatif tipe Inside Outside Circle (IOC) terhadap Hasil belajar peserta didik melalui metode eksperimen. Adapun dalam proses pelaksanaan penelitian, peneliti akan menggunakan kelas eksperimen dan kelas kontrol. Dimana kelas eksperimen yaitu yang akan diberi perlakuan (treatment) berupa model pembelajaran kooperatif tipe Inside Outside Circle (IOC), sedangkan kelas kontrol adalah kelas yang tidak diberi perlakuan (treatment) berupa model pembelajaran kooperatif tipe Inside Outside Circle (IOC). Metode yang akan digunakan dalam penelitian ini adalah true experimental design dengan menggunakan desain pretestposttest control group design.

Metode penelitian true experimental design menurut Sugiyono (2011:75) true experimental design adalah "desain penelitian dimana peneliti dapat mengontrol semua variabel luar yang mempengaruhi jalannya eksperimen". Ciri utama pengembangan dari metode penelitian true experimental design adalah sampel yang digunakan untuk eksperimen maupun sebagai kelompok kontrol diambil secara random dari populasi tertentu. 
Vol 2 No 1 Juli 2021

Jurnal AlphaEuclidEdu

Received:04/05/2021; Resived:04/06/2021; Accepted:04/07/2021

Sedangkan desain pretest-posttest control group design menurut Sugiyono (2011:76) pretest-posttest control group design adalah "desain yang menggunakan dua kelompok yang dipilih secara random kemudian diberi pretest untuk mengetahui keadaan awal adakah perbedaan antara kelompok eksperimen dan kelompok kontrol dan diberi posttes untuk mengetahui pengaruh perlakuan kelas eksperimen dan kelas kontrol secara signifikan".

Adapun Hipotesis dalam penelitian ini adalah "Ada pengaruh positif penggunaan model pembelajaran kooperatif tipe Inside Outside Circle (IOC) terhadap Hasil belajar peserta didik". Dengan standar kompetensi memahami kegiatan perekonomian Indonesia.

Sehingga yang menjadi variabel penelitian dalam penelitian ini adalah: 1) Variabel bebas adalah variabel yang mempunyai atau yang menjadi sebab perubahan atau timbulnya variabel terikat. Pada penelitian ini yang menjadi variabel bebas adalah model pembelajaran kooperatif tipe inside outside circle (IOC) (X), 2) Variabel terikat adalah variabel yang mempengaruhi atau yang menjadi akibat, karena adanya variabel bebas. Dalam penelitan ini yang menjadi variabel terikat yaitu Hasil belajar peserta $\operatorname{didik}(Y)$.

Populasi pada penelitian ini adalah seluruh peserta didik kelas VIII semester genap SMP Negeri 4 Metro yang terdiri dari 8 kelas yaitu kelas VIIIA, VIIIB, VIIIC, VIIID, VIIIE, VIIIF, VIIIG dan VIIIH dengan jumlah 189 peserta didik.

Dalam penelitian ini sampel menggunakan dua kelas. Penentuan sampel menggunakan teknik Cluster Random Sampling. Dimana penentuan kelas dilakukan dengan undian yang langkah-langkahnya: 1) Membuat daftar nama kelas, 2) Memberi kode pada nama kelas dengan angka, 3) Menulis kode pada selembaran kertas ukuran 2 x $2 \mathrm{~cm}, 4)$ Menggulung kertas ke dalam kaleng dan diundi, dan 5) Mengambil kertas gulungan dan membukanya.

Setelah pengambilan sampel selesai dilaksanakan ternyata yang terpilih adalah kelas VIII B yang berjumlah 22 peserta didik sebagai kelas eksperimen yang diberikan perlakuan berupa model pembelajaran kooperatif tipe Inside Outside Circle (IOC) dan kelas VIII C yang berjumlah 22 peserta didik sebagai kelas kontrol yang tidak diberikan perlakuan berupa model pembelajaran kooperatif tipe Inside Outside Circle (IOC).

\section{Hasil dan Pembahasan}

\subsection{Hasil}

Berdasarkan penelitian yang telah dilakukan oleh peneliti dapat disimpulkan bahwa ada pengaruh yang positif model pembelajaran kooperatif tipe Inside Outside Circle (IOC) terhadap Hasil belajar peserta didik kelas VIIIB, semester genap SMP Negri 4 Metro. Sehingga Hipotesis dinyatakan diterima. Hal ini dibuktikan dengan adanya peningkatan Hasil belajar peserta didik sebelum mendapat perlakuan berupa model pembelajaran kooperatif tipe Inside Outside Circle (IOC) dan setelah mendapat perlakuan berupa model pembelajaran kooperatif tipe Inside Outside Circle (IOC). 
Vol 2 No 1 Juli 2021

Jurnal AlphaEuclidEdu

Received:04/05/2021; Resived:04/06/2021; Accepted:04/07/2021

Kerangka berpikir merupakan hasil pemikiran peneliti berdasarkan teori atau konsep yang ada tentang variabel yang diteliti dan dirumuskan dari masalah penelitian. Menurut Sugiono (2011:60) mengemukakan bahwa "kerangka berpikir adalah konsep yang berisikan hubungan klausal antara variabel bebas dan variabel terikat dalam rangka memberikan jawaban sementara terhadap masalah yang akan diteliti." Variabel $\mathrm{X}$ dalam penelitian ini adalah model pembelajaran kooperatif tipe Inside Outside Circle (IOC) yaitu salah satu model pembelajaran dengan sintaks: pengarahan, buat kelompok heterogen, dengan membentuk lingkaran kecil dan lingkaran besar di mana peserta didik saling membagi informasi pada saat yang bersamaan dengan pasangan yang berbeda dengan singkat dan teratur. Sedangkan variabel $\mathrm{Y}$ dalam penelitian ini adalah Hasil belajar peserta didikyaitu perubahan kemampuan dalam diri peserta didik berdasarkan tahapan pencapaian pengalaman belajar yang dapat diamati dan diukur dengan nilai yang berupa angka dalam bentuk pengetahuan, sikap dan ketrampilan.

Berikut ini dibuat kerangka anggapan dasar untuk memberikan gambaran lebih jelas mengenai kerangka pemikiran di atas.

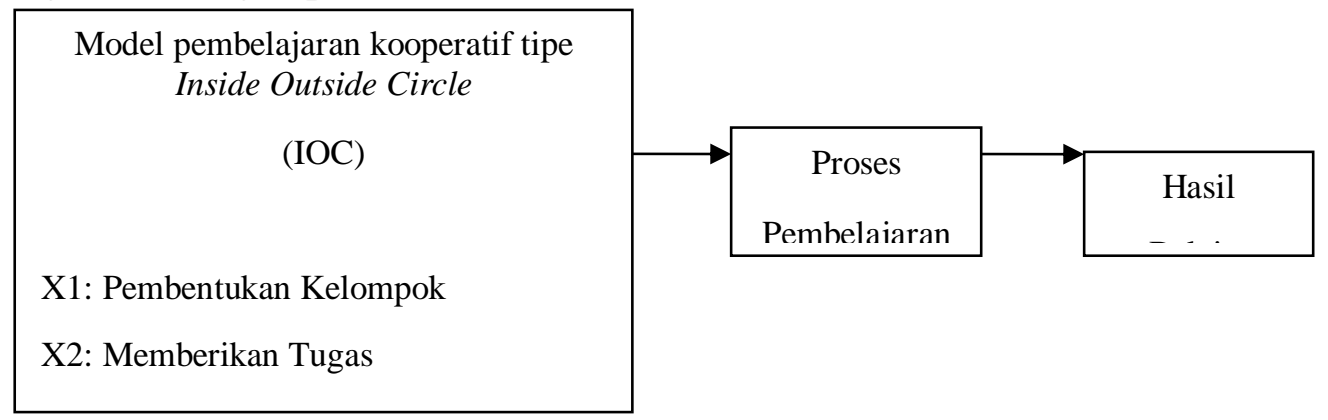

Gambar 1. Kerangka Anggapan Dasar

Adapun kerangka analitik dalam penelitian ini adalah:

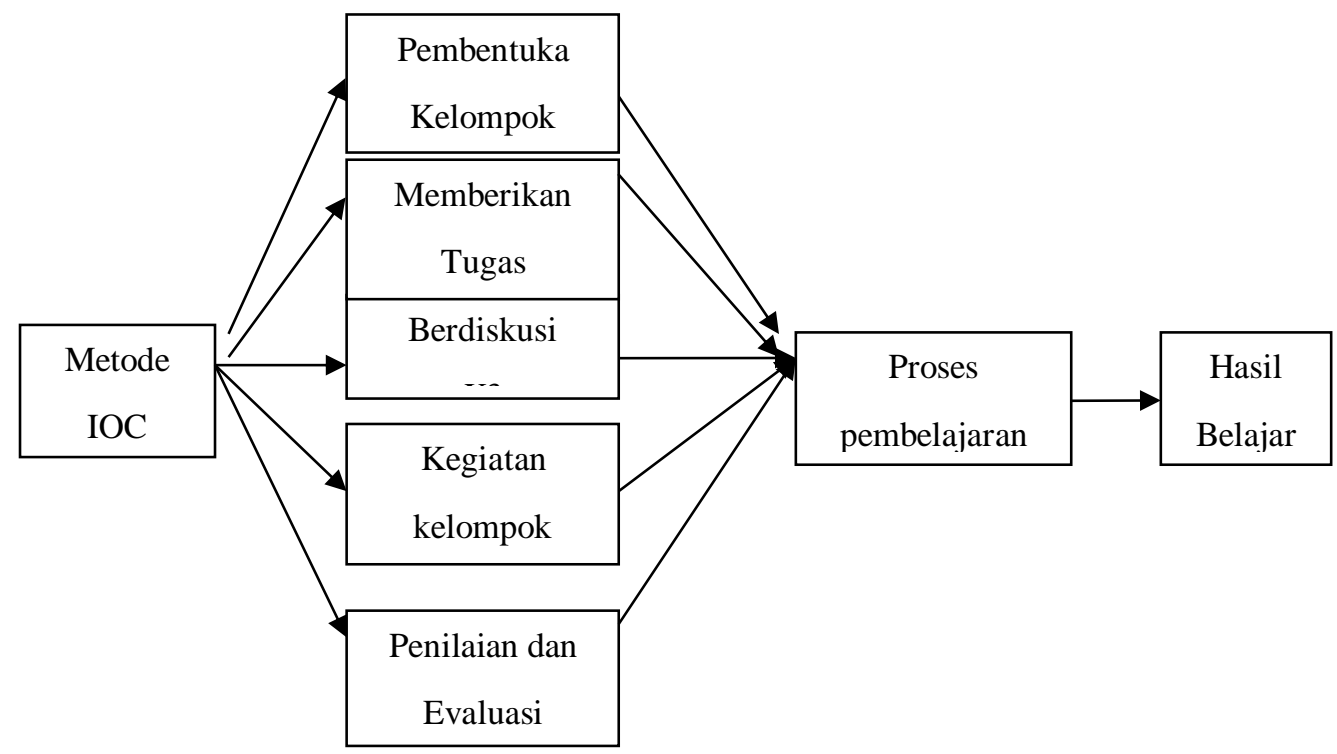

Gambar 2. Kerangka Analitik 
Vol 2 No 1 Juli 2021

Jurnal AlphaEuclidEdu

Received:04/05/2021; Resived:04/06/2021; Accepted:04/07/2021

Sedangkan paradigma dalam penelitian ini dapat digambarkan sebagai berikut:

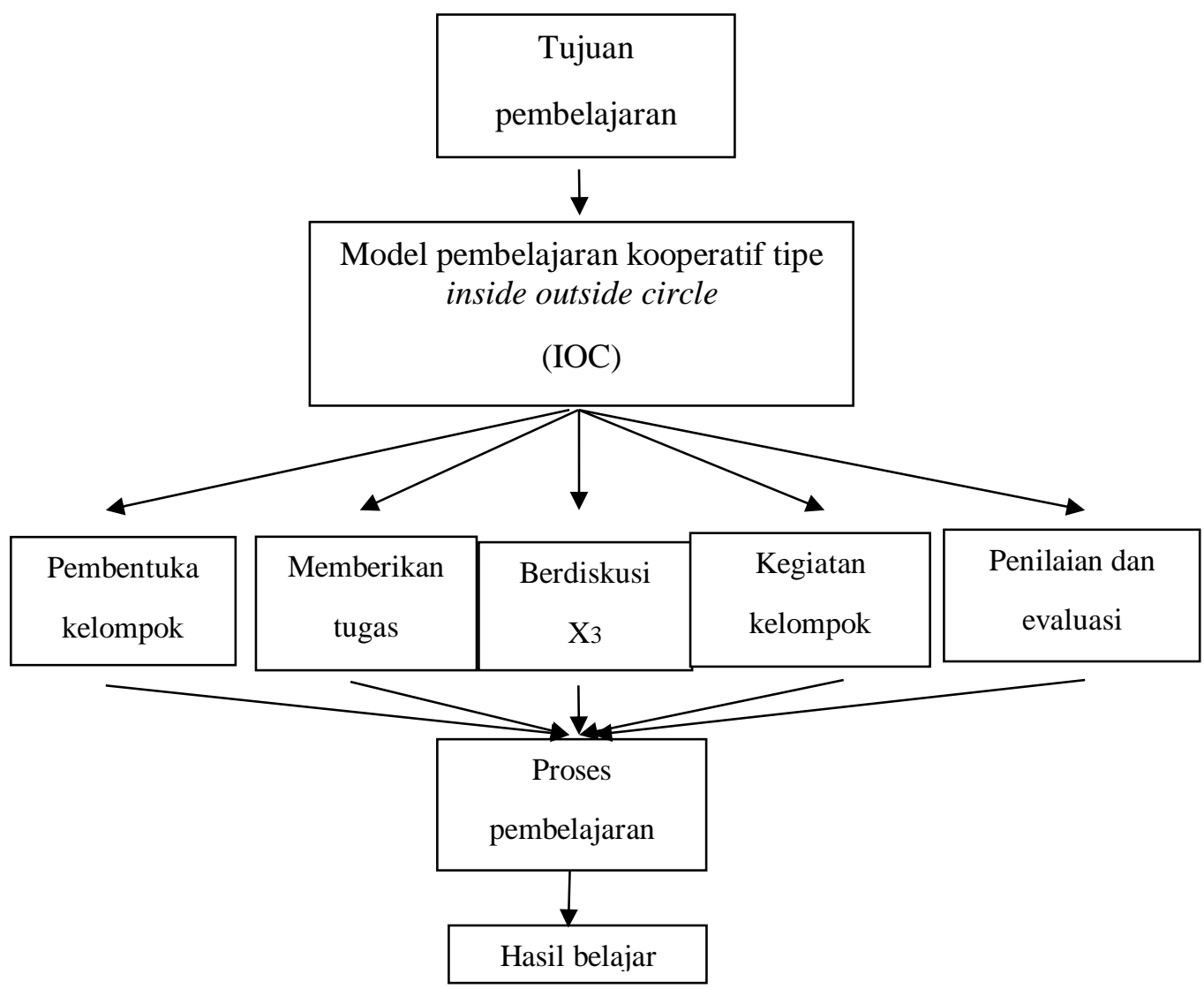

Gambar 3. Paradigma Penelitian

\subsection{Pembahasan}

Model pembelajaran kooperatif adalah model pembelajaran gotong-royong yang mendorong peningkatan kemampuan peserta didik dalam memecahkan berbagai permasalahan yang ditemui selama pembelajaran berlangsung, karena peserta didik dapat bekerja sama dengan peserta didik lain dalam menemukan dan merumuskan alternatif pemecahan terhadap masalah materi pelajaran yang dihadapi.

Model pembelajaran kooperatif tipe Inside Outside Circle (IOC) adalah salah satu model pembelajaran dengan sintaks: pengarahan, buat kelompok heterogen, dengan membentuk lingkaran kecil dan lingkaran besar di mana peserta didik saling membagi informasi pada saat yang bersamaan dengan pasangan yang berbeda dengan singkat dan teratur. Pembelajaran ini juga melibatkan lebih banyak peserta didik yang menelaah materi yang tercakup dalam suatu pembelajaran dan mengecek pemahaman mereka terhadap isi pelajaran tersebut. Guru dapat memberi ulasan maupun mengevaluasi halhal yang telah didiskusikan.

Menurut Suprijono (2009:98); (Sulistyowati, 2016) ada 5 indikator dalam model pembelajaran kooperatif tipe Inside Outside Circle (IOC), yaitu: 1) Pembentukan kelompok; Guru membagi peserta didik dalam kelompok beranggotakan 10 orang dan kepada setiap anggota berdiri membentuk lingkaran dalam melingkar menghadap keluar 
Vol 2 No 1 Juli 2021

Jurnal AlphaEuclidEdu

Received:04/05/2021; Resived:04/06/2021; Accepted:04/07/2021

dan lingkaran luar berdiri melingkar menghadap ke dalam. Dengan demikian antara anggota lingkaran dalam dan lingkaran luar saling berpasangan disebut kelompok asal, 2) Memberikan tugas; Guru memberi tugas tiap-tiap pasangan asal itu sesuai dengan indikator pembelajaran yang dirumuskan, 3) Berdiskusi; Memberikan waktu secukupnya untuk berdiskusi kepada tiap-tiap pasangan, 4) Kegiatan kelompok; Setelah mereka berdiskusi, guru meminta kepada anggota kelompok yang berada di lingkaran kecil diam di tempat, sementara anggota kelompok yang berada di lingkaran besar bergeser satu atau dua langkah searah perputaran jarum jam. Setiap pasangan terbentuk pasangan baru. Pasangan ini wajib memberi informasi berdasarkan hasil diskusi dengan kelompok asal, demikian seterusnya. Pergerakan akan berhenti jika anggota kelompok lingkaran dalam dan lingkaran luar bertemu dengan pasangan asal. Hasil diskusi di tiap-tiap kelompok besar tersebut dipaparkan sehingga terjadilah diskusi antar kelompok, 5) Penilaian dan evaluasi; Guru memberikan ulasan dan mengevaluasi halhal yang telah didiskusikan.

Hasil belajar peserta didik adalah perubahan kemampuan dalam diri peserta didik berdasarkan tahapan pencapaian pengalaman belajar yang dapat diamati dan diukur dengan nilai yang berupa angka dalam bentuk pengetahuan, sikap dan ketrampilan. Hasil belajar peserta didik juga merupakan bentuk nyata dari aktivitas dalam berinteraksi dengan individu atau kelompok. Sedangkan menurut Ahmadi (2004:138); (Wardah, 2014) menyatakan bahwa Hasil belajar peserta didikdipengaruhi oleh: 1) Faktor intern, meliputi: tujuan, minat, aktivitas, kecakapan, kebiasaan belajar serta penguasaan bahan pelajaran, 2) Faktor ekstern meliputi: Faktor lingkungan sekolah, berupa cara memberi pelajaran dan bahan-bahan bacaan, alat peraga dan sebagainya, Faktor lingkungan keluarga, meliputi perhatian orang tua, sarana dan prasarana belajar di rumah dan sebagainya, dan Faktor lingkungan masyarakat yaitu tempat tinggal peserta didik tersebut.

Dari hasil pengumpulan data yang dikumpulkan dari 22 orang peserta didik yang diberikan perlakuan (tretment) dengan model pembelajaran kooperatif tipe Inside Outside Circle (IOC), Hasil belajar peserta didik yang masuk dalam kategori tuntas sebanyak 68,18\% yakni 15 orang peserta didik dan yang belum tuntas 31,82\% yakni 7 oarang peserta didik dan pada pengujian dengan menggunakan rumus Regresi Linear Sederhana diperoleh $\alpha=55,5505+\mathrm{b}=0,3183$ sehingga demikian $\hat{Y}=\alpha+\mathrm{bx}$ adalah $\widehat{Y}=55,5505+0,3183 x$ kemudian dari hasil analisis diperoleh bahwa ada pengaruh yang positif model pembelajaran kooperatif tipe Inside Outside Circle (IOC) terhadap Hasil belajar peserta didik kelas VIII B SMP Negri 4 Metro. Hal ini dibuktikan dengan perhitungan analisis bahwa $t_{\text {hitung }}>t_{t a b}$ dan terlihat pada taraf signifikan $5 \%$ adalah 2,90 >1,72 dan pada taraf signifikan $1 \%$ yaitu 2,90>2,53 yang dapat dilihat pada tabel G statistik. Dengan demikian maka hipotesis diterima. Jadi ada pengaruh yang positif model pembelajaran kooperatif tipe Inside Outside Circle (IOC) terhadap Hasil belajar peserta didik kelas VIIIB, semester genap SMP Negri 4 Metro. 
Vol 2 No 1 Juli 2021

Jurnal AlphaEuclidEdu

Received:04/05/2021; Resived:04/06/2021; Accepted:04/07/2021

\section{KESIMPULAN DAN SARAN}

\subsection{Kesimpulan}

Berdasarkan hasil penelitian dan pembahasan yang telah dipaparkan sebelumnya dapat disimpulkan bahwa ada pengaruh yang positif model pembelajaran kooperatif tipe Inside Outside Circle (IOC) terhadap Hasil belajar peserta didik kelas VIIIB, semester genap SMP Negeri 4 Metro.

\subsection{Saran}

Berdasarkan kesimpulan yang diperoleh selama melaksanakan penelitian dan hasil pengamatan dalam penelitian, maka penulis mencoba mengemukakan saran-saran guna meningkatkan hasil belajar peserta didik sebagai berikut: 1) Dalam rangka meningkatkan hasil belajar pokok bahasan memahami kegiatan perekonomian Indonesia peserta didik lebih aktif dengan menggunakan model pembelajaran kooperatif tipe Inside Outside Circle (IOC). Karena peserta didik dapat bekerjasama dan aktif serta sama-sama meningkatkan hasil pemikiran guna mencapai suatu hasil belajar yang maksimal baik secara individu maupun dalam kelompok, 2) Dalam proses pembelajaran guru sebagai pelaksana proses pembelajaran diharapkan dapat menggunakan model pembelajaran yang sesuai dengan materi yang akan disampaikan. Peneliti menyarankan agar guru menggunakan model pembelajaran kooperatif tipe Inside Outside Circle (IOC) pada materi memahami kegiatan perekonomian Indonesia karena model pembelajaran ini dianggap sesuai dan dapat meningkatkan hasil belajar peserta didik.

\section{Referensi}

Arikunto, Suharsimi. 2006. Dasar-Dasar Evaluasi Pendidikan. Jakarta: Rhineka Cipta. 2010. Prosedur Penelitian Suatu Pendekatan Praktik. Jakarta: Rhineka Cipta.

Ahmadi, Abu. 2004. Psikologi Belajar Adisi Revisi. Jakarta: Rhineka Cipta.

Depdiknas.2003. Undang-undang RI No. 20 tahun 2003. Tentang Sistem Pendidikan Nasional.

Hamalik, Oemar. 2011. Proses Belajar Mengajar: Jakarta: Bumi Aksara.

Huda, Miftahul. 2013. Cooperative Learning: Metode, Teknik, Struktur dan Model Penerapan. Yogyakarta: Pustaka Belajar.

Ibrahim, Muslim. 2000. Pembelajaran Kooperatif. Surabaya: Unesa.

Isjoni. 2012. Cooperative Learning: Efektifitas Pembelajaran Kelompok. Bandung: Alfabeta.

Kunandar. 2007. Guru Profesionaledisi Revisi. Jakarta: Raja Grafindo Persada.

Lie, Anita, 2010. Cooperative Learning : Mempraktikkan Cooperative Learning di Ruang-ruang Kelas. Jakarta : PT. Grasindo.

Sanjaya, Wina. 2010. Strategi Pembelajaran: Berorientasi Standar Proses Pendidikan.

Slavin, Robert E. 2010. Cooperative Learning: Teori, Riset dan Praktik. Bandung: Nusa Media.

Sudjana. 2005. Metode Statistika. Bandung: Nusa Media.

Sugiyono. 2010. Statistika untuk penelitian Bandung: Alfabeta.

2011. Metodologi Penelitian Kuantitatif Kualitatif Dan R\&D. Bandung: Alfabeta.

Sulistyowati, E. (2016). Pengaruh Model Pembelajaran Kooperatif Tipe Two Stay Two Stray dan Numbered Head Together Terhadap Prestasi Belajar. 
Vol 2 No 1 Juli 2021

Jurnal AlphaEuclidEdu

Received:04/05/2021; Resived:04/06/2021; Accepted:04/07/2021

Perpustakaan.Uns.Ac.Id, 147, 11-40.

Suprijono, Agus. 2009. Cooperative Learning. Yogyakarta: Pustaka Belajar.

Undang-Undang Republik Indonesia No. 22 tahun 2006 tentang tujuan pendidikan nasional. 2009. Solo: Sendang Ilmu.

Universitas Muhammadiyah Metro. 2008. Pedoman Penyusunan Karya Ilmiah edisi revisi: Skripsi, Artikel, dan Makalah. Metro: Fakultas Keguruan dan Ilmu Pendidikan.

Wardah, W. (2014). Metacognitive Reading Strategy Enhancing English Reading Comprehension. At-Turats, 8(1). https://doi.org/10.24260/at-turats.v8i1.107. 